\title{
Legal marketing: proposition for a conceptual definition
}

\section{Chiara da Silva Simões*}

Lutheran University Center of Manaus,

Avenida Carlos Drummond de Andrade,

Conjunto Atílio Andreazza, 1460,

Japiim, 69077-730 Manaus,

Amazonas, Brazil

Email: chiarasimoes1@gmail.com

*Corresponding author

\section{Daniel Nascimento-e-Silva}

Federal Institute of Education, Science and Technology of Amazonas (IFAM) - Campus Manaus Distrito Industrial, Avenida Governador Danilo de Matos Areosa, 1731, Distrito Industrial, 69075-351 Manaus,

Amazonas, Brazil

Email: danielnss@gmail.com

\begin{abstract}
This study aims to present a proposal for a conceptual definition of legal marketing. It used the four stages of the conceptual bibliographic method, which is characterised by the formulation of a question of conceptual research, collection, and organisation of data for the generation of a conceptual response, to generate the definition sought from the state of the art of the established original concept marketing. The results pointed out process as the general equivalence term, and the characteristics that characterise the marketing found were creating value and supplying needs, translated as a common good. The conclusion shows that legal marketing is promoting the common good by drafting laws that promote social harmony. It differs entirely from what could today be called legal marketing, which is establishing communication channels to create personal or business value by supplying its clients' needs to obtain profit.
\end{abstract}

Keywords: legal marketing; conceptual definition; marketing; conceptual enunciation; advocacy marketing; legal advertising; advocacy advertising; attributes of legal marketing; legal marketing equivalence term; juridic services.

Reference to this paper should be made as follows: da Silva Simões, C. and Nascimento-e-Silva, D. (2020) 'Legal marketing: proposition for a conceptual definition', Int. J. Private Law, Vol. 9, No. 4, pp.272-294.

Biographical notes: Chiara da Silva Simões holds a Degree in Pedagogy from the Lutheran University of Brazil (ULBRA), a specialist in Psychopedagogy and School Management and supervision from the Maurício de Nassau College, Brazil. She is currently studying Law Degree at the Lutheran University of Brazil. Her areas of interest for study and research include tribute, social security, constitutional and civil law. 
Daniel Nascimento-e-Silva has a $\mathrm{PhD}$ in Production Engineering, with a Post-Doctorate in Management, both by the Federal University of Santa Catarina. He is a Professor and researcher at the Federal Institute of Education, Science and Technology of Amazonas, and also working on Master's courses in Professional and Technological Education and Doctorate in Technological Teaching, where he develops studies on new teaching procedures and builds theoretical schemes for a new education. He also collaborates with several research institutions, working in the fields of strategic management, new organisational models, building the theory of everything in the fields of human sciences and applied social sciences and conjunction of the integral human triad: body, mind and soul.

\section{Introduction}

If someone types the term legal marketing into Google's search engines, the result will yield more than five million records. The same procedure in Google Scholar, a popular scientific database, will only return 4,280 documents. When added the option in the title of the article, the result generates 68 papers. In summary, 4,280 records mention legal marketing, and only 68 have it as a central subject, but none of them define this phenomenon conceptually. It also means that this phenomenon is widespread technically and professionally but still unknown according to scientific dictates.

However, what is happening seems within the normal range of all the world's facts and phenomena. First, they appear, multiply, and diversify. As of diversification, they are gaining their contours and lives. It happened with biology, for example. Formerly one, today it presents diversities that range from neurology to exobiology, for instance. Marketing is similar. The diversity is so great that many areas already take on a life of their own, such as business marketing, government marketing, environmental marketing, service marketing, and so on. This list includes legal marketing, which has expanded so much that science must take it as an object to understand and explain it.

An example that demonstrates legal marketing's grandiosity is its gigantic national and transnational associations, such as the LMA (2020). These associations provide several essential services to their members, both legal services companies and lawyers, all aimed at acquiring knowledge and marketing skills centred on their clients' satisfaction and, of course, on making a profit. As shown in this study's theoretical framework, there is no difference between the marketing practiced by this company and all associations focused on legal marketing with the marketing practiced by purely commercial companies. In all of them, marketing is an instrument at the service of supplying needs to obtain profit. Scientifically, therefore, corporate marketing is what they practice. It is not legal marketing.

For science, the success or failure of the phenomena does not matter, but their proper explanation. Science does not have to agree with what the LMA says legal marketing is and what it's associates practice. Science searches, catalogues, classifies, organises, creates meanings in the world's facts and phenomena. This is the first taxonomic challenge facing what everyone is calling legal marketing.

In this sense, this study aims to present a proposal for a conceptual definition of the phenomenon of legal marketing. For this, it used the conceptual bibliographic method by (Nascimento-e-Silva, 2012, 2020; Silva et al., 2020), which is characterised by the 
formulation of a research question, collection, and organisation of data to generate an answer. Since legal marketing does not have a conceptual proposal, we analysed the definitions of the original concept marketing, determining its state of the art to cover the definition generated for the field of law, through derivation, with the necessary incorporations of legal specificities. The result was a definitive proposal that contemplates the rigors of science to establish what legal marketing is.

\section{Structural, operational and teleological aspects of marketing}

Marketing is a relatively simple phenomenon to be understood. This phenomenon comprises every supply effort, which begins with a survey of the needs of the environment where the demands originate (Khosravizadeh et al., 2020; Montoya-Restrepo et al., 2020). It proceeds with the determination of objectives and strategies (Blagorazumnaia and Robu, 2020; Liang and Gao, 2020), continues with the communication of these strategies from structures oriented to the operationalisation of supply (Sun et al., 2020; Yaghin, 2020), and ends with the delivery of products and services to claimants, as summarised in Figure 1. This logical scheme is in practically all types of organisations. It has been called strategic marketing management, as can be seen in the study by Vilkey and Dehbid (2016), Voskresenskaya et al. (2020), Bran-Piedrahita et al. (2020) and Kong et al. (2020), among countless others.

Figure 1 Marketing as a phenomenon

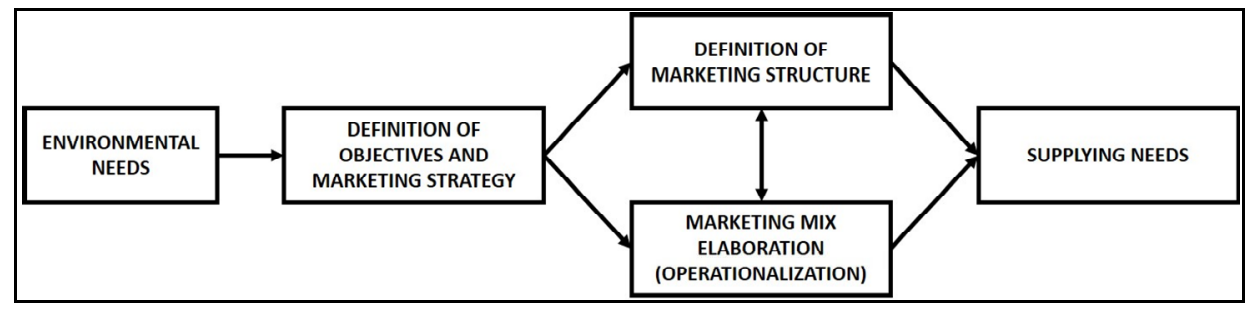

Source: Prepared by the authors

From an organisation's point of view, marketing is considered one of the three essential functions responsible for its functioning and development. The other parts are finance and production. The logical scheme of this triad is as follows. Marketing is in charge of supply, which means to detect and supply needs. Production is responsible for producing the product or service following the information provided by marketing. And finance is responsible for receiving monetary compensation from the recipient of the product and honouring commitments to the organisation's suppliers. How it works depends on the organisational mission, which is the reason for its existence (Coelho et al., 2020; Araújo et al., 2020; Hersberger-Langloh et al., 2020).

Organisational missions are operationalised based on a specific global strategy called a corporate system, involving the entire organisation and aiming at long-term objectives. Strategies are the path through which the organisation intends to achieve its goals (Sayyadi, 2019; Junita et al., 2020). As they cannot do this alone, organisations associate with others, sometimes forming a long chain of suppliers and distributors. The former supply them with all types of resources transformed into products and others used in their 
operation; the seconds help them make their products available to the end customer. Ultimately, marketing is the organisational function responsible for this organisational macro-orientation, with the production and finance functions' help.

These functions perform three constant flows. The first starts with customers through marketing efforts, which aims to identify the needs of customers. Together with the production function, they translate those needs into the product or service from specific attributes and expected benefits. Afterward, the supply and materials programming is negotiated with the suppliers for the production to take place. This flow that begins at the customer and ends at the suppliers is called informational, under marketing responsibility. With the approved production schedule, the production flow starts with the first supplier. It continues with the others until the organisation can produce the product demanded and deliver it to the first distributor. This wholesaler sells to retailers and selling to the final consumer. In possession of the product, the customer pays the retailer who keeps his monetary part and delivers the wholesaler's amount, which, in turn, does the same with the producing industry until all suppliers have their share, materialising the cash flow or financial.

These three flows control almost all organisations' daily lives, whether public or private, with or without beneficial interest. It means that the macro-flow of marketing is practiced globally but does not serve all types of organisations. It only applies in its entirety to those who have a clear financial interest, even if disguised discursively as customer satisfaction or added value. In a car factory or bank, all stages of the marketing phenomenon are observed. This practice intends to generate profits, which will reward investors and all individuals involved in the production and support of it.

Regarding the legal marketing phenomenon, for example, things change. Reasoning in reverse, there is no product to be sold, much less the generation of profits. As will be shown later, the outcome of legal marketing is the law. And nobody can go around selling the law. Consequently, the types of organisations involved in producing a law differ significantly from those participating in other production, supply, and distribution chains. But, if there is production, there is a production system. As a system, there will also have to be inputs (and suppliers) of resources transformed into outputs (the laws). Finally, if there is a production system, marketing is essential. So, what kind of marketing is this? There are three fundamental dimensions to clarify the need for a conceptual delimitation of legal marketing. These dimensions differentiate it from other concepts improperly used: marketing structures, its operational structure, and its teleological nature.

\subsection{Marketing structures}

Once the organisational strategy is defined, its operationalisation is defining the internal and external marketing structures. When talking about organisational structure, it is referring to formal relationships between people (Silvianita and Ling, 2020), defining authorities and control schemes (Awada, 2019; Silva et al., 2019a), the forms of coordination (Membiela-Pollán, 2019; Aggarwal and Kapoor, 2020), among other essential definitions. It also involves determining what people have to do, their tasks and activities, in short, the division of labour (Silvianita and Ling, 2020; Hanafi, 2019; Awada, 2019; Eugenia et al., 2019; Wahab and Nazri, 2019; Moura et al., 2019; Silva et al., 2019a; Membiela-Pollán, 2019; Bashir and Verma, 2019). People handle resources (Silvianita and Ling, 2020) based on the orientation of specific processes (Awada, 2019) 
to achieve organisational goals (Awada, 2019; Bashir and Verma, 2019). All of this is done from a structured communication system.

The strategy defines the organisational structure (Neis et al., 2017; Peng, 2019; Alabina and Mishchenko, 2019). It is where the different structuring schemes come in. As organisations are human groupings with specific aims, it is necessary to define adequately what, how, and when to do according to specific quality standards. Quality standards are customer guidelines that guide the supply of their needs. If these guidelines do not exist, the likelihood of dissatisfaction increases and negatively impacts the organisation's business. If the company fails, it is because the organisation has been unable to fulfil its mission, or its mission was not in the interest of the environment. It is the first marketing challenge of all types of business organisations: to organise yourself internally so that your customers' satisfaction is guaranteed at a minimum cost to generate the highest possible revenue.

As the organisation cannot control what is beyond its reach, it articulates inter-organisational strategies to expand its action field. It will seek, for example, to create and participate in the management of its supply chains (Majercak et al., 2016; Forozandeh et al., 2018), which is a form of inter-organisational integration with several objectives, mainly the guarantee of supply, cost reduction, revenue increase, technology exchange, among others.

The literature reports financial gains as the most relevant resulting from marketing's external structures (Deng et al., 2020; Ali and Kachroo, 2020; Tikhonov et al., 2020; Muhammad et al., 2020). Technically are called marketing channels or marketing channels, and these structures benefit those who participate in them (Deng et al., 2020; Shafiei and Modarres, 2020; Ali and Kachroo, 2020). But it is necessary to pay attention to the size they reach since structures with many participants affect the net price of the product (Ali and Kachroo, 2020), just as the right choice of the dealer increases margins (Tikhonov et al., 2020) and the price transmission elasticity affects marketing (Widyaningsih et al., 2020). To suit the strategy, in the event of failure, the structures need to be changed.

The study by Gowsalya et al. (2020) presents an internal marketing structure composed of anglers, fish classifiers, and price negotiators (one for the local market and the other for direct sale to consumers). Jadhav and Borgave (2020) analyse six long external marketing structures (fisherman, local seller, commissioned agent, retailer, and consumer) and a short one (fisherman and consumer). Meltem and Mevlüt (2020) studied five structures, the longest being composed of the farmer, broker, exporter, retailer, and consumer, while the shortest formed by the farmer and consumer, very similar to the structure described by Özenç and Mevlüt (2020). Gebretsadik (2020) studied sesame's marketing structure and found producers, buyers from producers, local beneficiaries, cooperatives, exporters, and processors as members. Joyce et al. (2019) report a little structure composed of the producer, retailer, and consumers and another long one, in which producers, collectors, wholesalers, retailers, and consumers participate. Finally, Muhibbullah and Karim (2016) describe an organisation's experience that maintains a domestic marketing structure and another for the foreign market.

The strategy is dependent on external market intelligence and internal business intelligence (Wang et al., 2020). Some organisations have used artificial intelligence to make their marketing structures' adequacy more effective to support their strategies, as shown by the research carried out by Kaiyp and Alimanova (2020). The authors found 
that artificial intelligence affects the structure and added value to the customer, organisation, and management.

There are still several misunderstood and inadequately used marketing concepts (Vynogradova and Drokina, 2020), that even successful organisations and individuals still use. Marketing structures and distribution channels are aspects of the same practice when viewed holistically (Yeserah et al., 2019), integrated. If someone sees layers and another sees levels (Clarke, 1999), they describe the same reality differently.

Given the extraordinary dynamism of the development of the marketing phenomenon in all spheres of associated human life, notably in the legal field, it is already possible to perceive three marketing structures. Two of them faithfully follow business companies' customary practices: the marketing of companies providing legal services and the marketing performed by lawyers, legal professionals. Large legal companies organise themselves to carry out surveys on their market needs, update their business strategies, and, from there, their marketing structure. Since they do not produce the laws, their positions are along the distribution chain. Large legal firms seem to operate like wholesalers and smaller ones, like retailers. Lawyers who work autonomously fulfil the retail function.

Both legal services companies and lawyers can join with other companies, national and international, configuring an expanded marketing structure like industries, businesses, and other service providers. It needs to happen so that they can reap the benefits of a typical supply chain. The external marketing structures are the distribution channels, which make up one of the essential aspects of the so-called marketing mix. The marketing structure operationalises the strategy: defining price, product, place, and promotion, the so-called 4Ps, which, even though they have no scientific basis (Goi, 2009), are widely used in business management.

\subsection{The operational dimension of marketing}

Marketing operates in what is known as the marketing mix, consisting of price, product, place, and promotion, synthetically called 4P. Some studies point to 7Ps (Xaiver et al., 2020; Bodet and Séguin, 2020; Kumar and Almoula, 2020; Ravangard et al., 2020), adding people, processes and physical evidence and up to 9Ps (Pater and Cristea, 2018; Nugraha et al., 2020), adding programming and policies. This variable number of Ps is the visible evidence of something invisible: the need for organisations to control what is not controllable, which is consumer behaviour.

In the marketing mix, everything is defined based on the satisfaction of the target market's needs (Khorsheed et al., 2020; Xaiver et al., 2020; Lagzouli et al., 2020; Al-Zyoud, 2019) and customers and consumers (Beqaj et al., 2019; Goi, 2009; Roache, 2019; Pong and Chin, 2020). But what is effectively behind the efforts to satisfy needs and add value is the acquisition of profit from the achievement of organisational and marketing objectives (Kotler et al., 2006; Bennett, 1995; Zineldin and Philipson, 2007; Kotler, 1994; Xaiver et al., 2020; Almakhadmah and Ajloun, 2019; Maulana and Susandy, 2019). The profit from the marketing mix is almost always financial. It is the outcome of the difference between the revenues earned from the investments made. It is the general rule for all types of enterprises with economic purposes.

However, from legal marketing, the marketing mix in its entirety is performed by companies providing legal services and independent legal professionals, and lawyers. They must use these procedures and techniques appropriately to understand their 
customers' needs adequately, format the services following those needs, and deliver to them as soon as possible and at a cost that they can afford.

Legal services companies and lawyers do not make laws. The laws, provided by their producers, are their raw materials, not their products. From the reception of laws, these companies and professionals organise their services, which configure their products. Depending on the structure of marketing, finance, production and support services, and the distribution and promotion channels, these services have cost so that each one has a price. The price represents the agreed value sufficient to recover the companies' investments and the lawyer, in the case of a self-employed professional, plus a profit margin. There can be new investments and improvement of the services provided. Profit, therefore, is vital for legal services and legal professionals. But it seems that the profit does not apply to legal marketing, only to business marketing for legal services.

\subsection{The teleological dimension of marketing}

Every organisation has a reason for existence, a mission. Marketing is also an organisation in its forms because it represents associated human efforts towards a specific objective. That determined objective is that it allows knowing what its purpose is, its teleological nature. The knowledge of the purpose enables us to understand with precision the ontological character of all conceptual definition. When it knows the meaning of something, it understands its scope, its boundaries. The literature review showed that the great diversity of existing marketing always points to the same purpose.

The study by Opriş et al. (2014) deals with ecological marketing, eco-marketing, whose aim is to change consumer behaviour. The research by Agapito et al. $(2012,2013)$ dealt with sensory marketing to adapt a brand to the customers' lifestyle. While the first wants to change people's behaviour based on marketing efforts, the second intended the opposite, to adapt the product to people. Stoica et al. (2015) show that online marketing is to exchange ideas, products, and services that satisfy customers. It is the predominance in literature: the idea of exchange.

The purpose of marketing as an exchange, which is natural, must guarantee the company's efficient growth (Zaharia and Dogaru, 2013). It increases the financial volume of business (Constantinescu and Marinescu, 2014), build lasting brands (Mudzanani and Molaoa, 2018), and provided that with the generation of financial profit and economic benefits for the company and its stakeholders (Sinanagić et al., 2019). A company is an investment, and every investment must have the return of what was invested plus an additional remuneration. That is the dynamics of every business, practiced by every business organisation, including large companies that provide legal services, independent professionals, and lawyers. Therefore, what these companies and lawyers' practice is not legal marketing but business marketing. And so, it needs to be.

\section{Research methodology}

This study used the survey method to generate its results. This method consists of selecting a sample with all the characteristics of a population. The analysis unit consists of each conceptual definition found, whose analysis level was the conceptual scope taken around its terms of equivalence and attributes. The analysis perspective was synchronic or transversal, which seeks to explain the present reality of a given fact or phenomenon 
differently from the diachronic or longitudinal perspective, which is concerned with describing the marketing's temporal evolution.

\subsection{Guiding issues}

According to this study's theoretical framework, two central questions guided the operationalisation of its methodological strategy:

a What is the equivalence term of the definitions found in the literature that synthesises the marketing concept?

b What are the attributes of marketing that allow the understanding of the equivalence term found and that account for the specificity of legal marketing?

\subsection{Population and sample}

The population consisted of all scientific articles in the scientific databases (Google Scholar, Elsevier, Taylor \& Francis, Emerald, and Scopus) that presented at least one conceptual definition for Marketing. It used the temporal sampling scheme, in which time was cut, looking for conceptual definitions in articles published between the years 2018 and 2020, in a total of 16 papers found. It discarded responses for completing undergraduate and specialisation courses, given almost all these documents' theoretical and methodological weaknesses. All definitions found were validated and used in producing the results of this investigation.

\subsection{Data collection instrument}

We used the mass of data (Nascimento-e-Silva, 2012, 2020). This instrument consists of a table containing two columns. In the first, all the bibliographic information of the scientific documents placed. In contrast, in the second, the answers to the guiding questions found in the documents are recorded and their respective page number. This type of data collection instrument is called 'mass of data'. The greater the number of responses found, the greater the number of lines in the table, and the greater the data mass. The robustness of the masses of data depends on contemplating the largest possible number of responses found.

\subsection{Data collection strategy}

We collected the data according to the chronological order from 2018 to 2020. This procedure was due to the valid assumption that the state of the art constituted by the scientific production of the most recent years. This production would portray the most relevant and impacting papers in the form of reference, configuring the currently known about the phenomenon under study - the collection based on the previous determination of a response pattern. As the objective was to find answers to the question 'what is marketing?' we determined that the answers would have to come in the following way 'marketing can be defined as'. This decision intended to avoid the enormity of responses that could come with 'marketing is' standard. We discarded them for not being configured in a standard of conceptual definition. Another reason was that 'marketing can be defined as' externalises the authors' conscious will to present the concept's definition. 
In the search option, 'with the exact phrase', the procedure consisted of typing the pre-defined response pattern 'marketing can be defined as'. The answers sought appeared in bold, which facilitated the collection. So, we recorded them in the data mass and then the bibliographic reference. We do not collect definitions contained in the undergraduate and specialisation monographs. Many of these studies lack scientific rigor in applying the scientific method and the generation and discussion of its results. The resulting mass of data consisted of scientific articles published in scientific journals and the annals of events, master's theses, and doctoral theses.

\subsection{Data analysis procedure and interpretation of results}

In this study, the conceptual definitions are the statements found in the scientific literature. The enunciators are the scientific community, a normative instance, with its rules for acceptance for publication. The readers are the recipient of these publications (Paiero, 2011). From the scientific method, the science rules guarantee the minimum mutual trust for an utterance to be considered valid by the enunciates. That is because all communication needs a minimum of mutual trust (Fulaneti, 2010).

Figure 2 Structure of conceptual statements

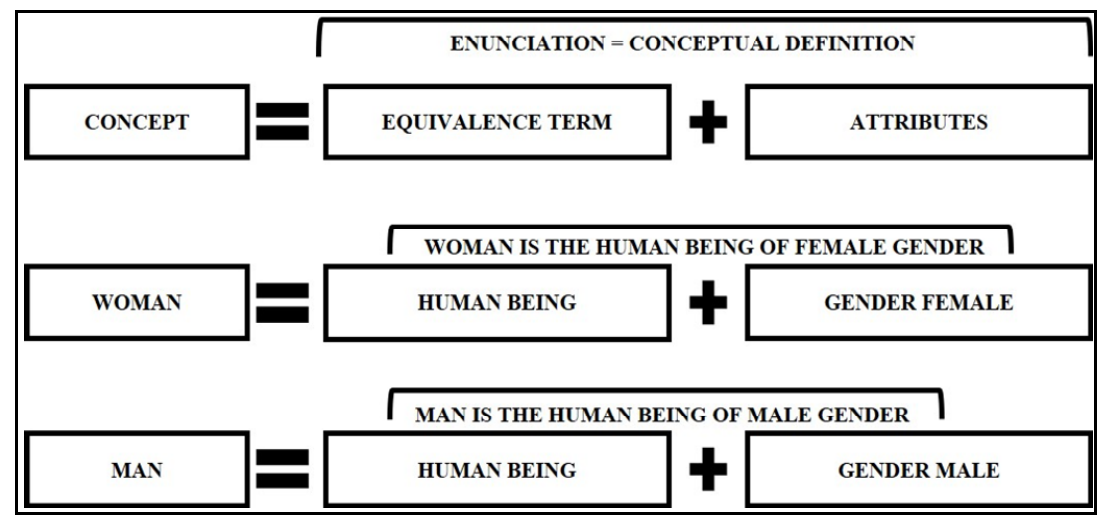

Source: Prepared by the authors

The statement (the conceptual definitions) is the discourse's product, while the affirmation is the act through which the speech is produced (Gebra and Ferranti, 2010). This final product, the statement, materialised in the conceptual definitions, presents a structure that can be analysed from the perspective of discursive syntax, as shown in Figure 2. The concept is the reality that one wants to explain and communicate through the definitions; we want to understand it precisely. The concept is what exists, and that is possible to communicate.

The definition is the statement that explains (describes) the concept and makes it understandable. Therefore, definitions are so that we can accurately understand what that part of reality is unknown. Then, it serves to make known what is unknown. It is this logic that permeates the construction of definitions and determines its structure. One piece is not known, which is the concept, in the figure placed on the left side of the equation, and another known part, which is the definition, is placed on the right side of the equation. 
The right side consists of two parts. The first is what can be called the term of equivalence. This term is a synonym, a word with the same semantic value as the concept where the meaning is unknown. This equivalence process transforms the unknown into the known, exchanges an unfamiliar image for another, known. If you do not know what 'man' is and if you know what 'human being' is, you will know what 'man' is if you become 'man' equivalent to 'human being'.

But defining concepts is not exchanging one word for another, one concept for another. After all, man and woman are human beings. It is necessary to differentiate these two concepts. That differentiation is made by identifying each concept's unique characteristics or, better saying, the equivalence term. And to point out unique features is to give them attributes. Then, the attributes are the second part of the conceptual definition, to differentiate from one concept to another. Women and men are human beings; they have the same equivalence term. But what will differentiate one from the other are its attributes, with sex being the most striking. Man has male sex (attribute); the woman has a female gender (attribute).

The combination of the equivalence term with the attributes generates conceptual definitions, conceptual statements. When it says that administration is the process of planning, organising, directing, and controlling resources to achieve organisational objectives, the word process is the term of equivalence. Resources and organisational objectives are the attributes (planning, organising, driving, and controlling are the steps in the process). It is the variations in attributes that expand the conceptual definitions from one field to the other.

Take administration's definition, called the original or primary definition, is the most comprehensive and is not derived from any other covering it. Financial management is a part of the more extensive administration. If it is a part, it will combine the same equivalence term as the primary definition and differentiated in the attributes. For example, financial management definition is "the process of planning, organising, directing and controlling financial resources to achieve organizational objectives" or so "financial management is the process of planning, organizing, directing and controlling the financial resources to achieve organizations' financial objectives." Secondary or derived definitions combine the same equivalence term and differ in attributes. We apply this rule to construct the conceptual definition of legal marketing, which science has not yet done. For this, it was necessary first to determine what marketing is, its conceptual definition from the state of science, and expand its conceptual statement to the legal field, differentiating its attributes.

After being collected, the data were subject to criticism so that there was a guarantee that they followed the conceptual pattern of type $\mathrm{A}=\mathrm{B}+\mathrm{C}$. A corresponded to the response pattern 'marketing can be defined as' $\mathrm{B}$ is the equivalence term definition, and $\mathrm{C}$ would correspond to the definition's attributes. We reject all responses other than this standard. We prepared a spreadsheet with terms of reference and bibliographic information

The analysis continued with the grouping of the terms of equivalence repeated so that it was possible to identify those with higher frequencies. That reduced the number of equivalence terms in the original spreadsheet. Then, the different equivalence terms in spelling were grouped around semantic equivalence (other words with the same meaning, as in 'procedure' and 'process') and then by semantic proximity (different but close meanings, as in 'action' and 'strategy'). With this procedure, it was possible to 
understand the scope of marketing from its terms of equivalence. It allowed us to find an equivalence term that covered all the others, restricting state of the art.

The next step was to identify its attributes, which are the characteristics that differentiate one thing from the other - that procedure allowed to analyse the terms of equivalence. The main difference was that the attributes varied considerably in quantity, while the equivalence term proved to be all unique for each definition. We noted all attributes found for the term of equivalence contained in each conceptual definition of each article. Therefore, the collection of attributes was much more extensive than that of the equivalence terms.

Each repeated attribute was quantified, reducing the data mass. Then they were grouped by synonymy (different words with the same meaning) and then by semantic field, as performed concerning the equivalence terms. We identify the characteristic attributes of marketing and find the logical scheme that united them and gave them meaning. The results made it possible to compose the conceptual definition sought and restrict the current knowledge about the investigated phenomenon, a necessary demarcation to present a valid conceptual proposal of legal marketing.

\section{Results and discussion}

Every concept, as a representation of reality, consists of two parts. The first is the equivalence term, which makes the unknown (the phenomenon one wants to know, conceptualise) known, and its attributes, which are aspects of reality that differentiate the phenomenon from any other. The procedures used to generate the results are in this section.

\subsection{Marketing: equivalent terms}

The results show that marketing is a set (Mendes, 2018; Rocha, 2018; Silva et al., 2019b), as shown in Table 1. This positioning is because actions and activities need to be planned, performed, and evaluated in their performance, composing a kind of constituent elements of these actions that form the set called marketing. Therefore, a group's idea is that these actions and activities include a whole that distinguishes this whole, called marketing, from other groups. It is the case of finance, operations, and communications, with which marketing is concerned communicates.

Management is another marketing equivalence term found in the literature (Nogueira, 2018), which encompasses how to manage (Dias, 2018) and organisational behaviour (Quintas, 2018). Management is planning, organising, directing, and controlling resources to achieve organisational objectives, adapted to marketing, and has communication efforts the primary resource to manage. For this reason, marketing is a way of managing organisational resources, as suggested by Dias (2018), which implies the adoption of specific organisational behaviour that allows the available resources directed towards the achievement of corporate objectives. 
Table 1 Marketing: terms of equivalence

\begin{tabular}{lcc}
\hline Authors & Equivalence terms & Constructs \\
\hline Mendes (2018), Rocha (2018) and Silva et al. (2019a) & Set & Set \\
Nogueira (2018) & Management & Management \\
Dias (2018) & Way of managing & \\
Quintas (2018) & Behaviour & \\
Queiroz (2018) & Action & Process \\
Macedo et al. (2018) & Procedure & \\
Gil (2018) and Sales and Sousa (2018) & Process & \\
Ferreira (2018) & Strategy & \\
Ferreira et al. (2019) & Tool & Relation \\
Severino (2018) & Combination & \\
Escudeiro et al. (2019) & Expression & \\
Fonseca (2018) & Use & \\
Souza et al. (2018) & Something engaging & \\
\hline
\end{tabular}

Source: Data collected by the authors

The third grouping of equivalence terms found in the literature is the process construct. The process is the logical sequencing of steps that, in the end, produce a specific desired result (Gil, 2018). Every process, in a generic sense, is an action (Queiroz, 2018), which follows particular procedures (Macedo et al., 2018) prescribed as a way in which specific objectives are achieved, configuring, in practice, what is called strategy (Ferreira, 2018). Thus, a process is a construct that involves action, procedure, and design.

The fourth grouping of equivalence terms defines marketing as a 'relationship'. The idea of a relationship is due to at least two actors who interact, so that relationship is interaction. This interaction, in marketing, is made from tools. It is a list of instruments (Ferreira et al., 2019), used in a combined way (Severino, 2018), often as a way of creative expression (Escudeiro et al., 2019), innovative. The greater the innovation caused in this relational scheme between the organisation and the external environment, the greater the institutionalisation of its use will tend to be (Fonseca, 2018) as a relational mechanism with the ground, which involves it (Souza et al., 2018).

Thus, the process seems to be the equivalence term capable of synthesising all equivalence terms found in the literature. This inference is that management, set, and relationship is an element of a more extensive set, which will be called a process in this work. Management is the process whose features are to plan, organise, direct, and control. These were a set to achieve objectives; every process is a set of logically ordered steps that generate a particular result; every relationship is a relational scheme. They are interactive practices.

\subsection{Marketing: attributes}

Attributes are a set of characteristics that things present and that distinguish them from each other. The literature presents them as a set of qualities associated with each other (Östborn, 2018) and that, in various ways, impact what they characterise (Delospital, 2016; Marques, 2009). It means that, as these characteristics change, the phenomenon 
changes. Take illiteracy and lack of mastery over phonemes as one of its attributes. The greater the lack of dominance, the greater the illiteracy. The smaller, the less illiterate someone considered. That is why it said that attributes are information about something (Santos, 2019) based on what can be identified and perceived in them (Peters and Remaud, 2020).

The facts and phenomena of the world are known for their attributes. It is the case with marketing. Table 1 shows its attributes catalogued by science. Among all the characteristics of the phenomenon, what draws attention is the predominance of 'creating value' (Macedo et al., 2018; Gil, 2018). It is the main attribute of marketing, so what distinguishes this phenomenon from all others is its ability to create value. This phenomenon is in different ways in the literature.

One of these forms is articulation (Quintas, 2018), the interplay between individuals, institutions, and organisations to produce beneficial results for these agents. This benefit is also present in the conception of Sales and Souza (2018), in which marketing allows people to obtain what they need. Although Dias (2018) and Escudeiro et al. (2019) characterise it as attracting customers, this ability is only possible if individuals, organisations, and institutions effectively demonstrate their power to create value, which is nothing more than 'to do the good'. If you do not do good, you are not attracted, much fewer relationships are maintained. That is the essence of marketing: doing good. It is by doing good that customers, friendships, relationships, and everything else are attracted. Table 2 shows the most common attributes of the marketing definitions.

Table 2 Marketing: attributes

\begin{tabular}{|c|c|}
\hline Authors & Attributes \\
\hline Mendes (2018) & Program design, implementation, and control \\
\hline Rocha (2018) & Program implementation and control \\
\hline Silva et al. (2019b) & Communication actions \\
\hline Fonseca (2018) & Communication channel \\
\hline Nogueira (2018) & Processes \\
\hline Dias (2018) & Attract new customers and keep current \\
\hline Quintas (2018) & Articulation with audiences \\
\hline Macedo et al. (2018) & Create value and build relationships \\
\hline Gil (2018) & Create long-term value and relationships \\
\hline Sales and Sousa (2018) & Getting what individuals and groups want \\
\hline Escudeiro et al. (2019) & Attract customers and maintain relationships \\
\hline Ferreira (2018) & Exchanges between members of the business chain \\
\hline Queiroz (2018) & Market \\
\hline Souza et al. (2018) & Identify and satisfy needs \\
\hline Ferreira et al. (2019) & Manage well \\
\hline Severino (2018) & Management tools \\
\hline
\end{tabular}

Source: Data collected by the authors

Based on this fundamental characteristic, it is possible to understand how the other attributes explain marketing as a process, as demonstrated in the analysis of equivalence terms, which is also one of the marketing characteristics (Nogueira, 2018). As a process, 
marketing is planning, executed, and evaluated around the effort to do good (Mendes, 2018; Rocha, 2018) to meet needs. And as it aims to permanence relationships, the plans are divided into sectoral programs and specific projects for a particular supply type.

In addition to being an attribute that quickly identifies marketing actions, communication is its primary tool (Silva et al., 2019a; Fonseca, 2018). As a process, it is necessary to identify needs, develop plans with the long-term objectives to be obtained, develop strategies into programs and projects, execute them, monitor their execution, evaluate their results, and correcting actions when necessary. It is all done in a dialogical way, between individuals, organisations, and institutions, which become partners in acquiring that good desired by all.

As everything produced consumes resources, the actors involved sharing everything necessary to invest in obtaining the good. For this, they make exchanges along the entire production chain (Ferreira, 2018) of good, which is how the word business, in practice, has meaning today. Doing business is doing good. Although many do good in exchange in some way, selfishly, that selfish supply is still good. To satisfy needs is to do good. By extension, the market (Queiroz, 2018) is an ample space where individuals, organisations, and institutions do good, selfishly, or through otherness.

Finally, but not least, managing this entire value creation system is a challenge for everyone who puts themselves at the service of good. It is not enough to work. It is necessary to manage well, transform management and its tools (Severino, 2018) into instruments for producing the good. Thus, the attributes of marketing orbit around creating value, which has communication as the fundamental tool for creating and maintaining relationships aimed at supplying needs. And the value of a law lies precisely in its contribution to the guarantee of social harmony. The value of legal marketing is the will. It comes with the assurance that the law gives to the citizens of a community. Therefore, it follows that the security of good and social harmony are the two attributes that summarise most appropriately all the others to represent the fundamental characteristics of legal marketing.

\subsection{Legal marketing: conceptual definition proposition}

According to this study's theoretical foundation, the conceptual expansion is from the differentiation of the concept's attributes. In the case of marketing, the conceptual definition prevalent in the original scientific literature can be summarised thus "marketing is the process of creating value from communication channels that aim to establish long-lasting relationships to supply needs." The first differentiation established is the specificity of the needs to be met.

In legal marketing, as the name suggests, the needs are of a legal nature. As the term 'legal' refers to the law (Pagura, 2010), these needs concern the laws demanded by a community. Healthy legal requirements that legal marketing's mission is to supply. Thus, the first approach for defining the concept would be "legal marketing is the process of creating value through communication channels that aim to establish long-term relationships to supply legal needs."

On the other hand, laws are not the products or services of individuals and organisations taken in isolation. Legislation, as a legal and juridical universe, is a type of institution, understood as the rules (written and unwritten) that govern a social system and that determine what is legitimate and what is not (Ramos and Nascimento, 2008; Leão et al., 2019; Silva et al., 2002). It makes the law a product owned by the society, not 
by private individuals and organisations. Therefore, the communication channels have institutions between sender and recipient, so only institutions can establish legal marketing communication channels.

An industry communicates through different channels the values that its products create for those who use them in meeting their needs. A hospital produces takes to society the communication of the creation of value that its services bring to those who use them to supply their needs. From this perspective, a law firm can do legal marketing because it is an institutional unit in communicating to society the demands that the laws can supply to create value for the community and its members. Its communication is institutional when it informs the significance of laws for social harmony, restoring possible anxieties and afflictions that arise from cases where the law is needy and demanding. But if he discloses his services or the company he is part of, it is no longer legal marketing, but attorney or business marketing.

Thus, the conceptual definition of legal marketing proposed is "legal marketing is the process of promoting the common good through the drafting of laws that promote social harmony." It is a process because it involves a logical sequence that begins with identifying demands for legislation. It continues with the drafting and application of laws and continues indefinitely with communication efforts so that regulations are known to citizens. The law itself, therefore, is a common good for all, available to all, as an inalienable right. Social harmony is the purpose of this type of marketing.

Therefore, these results suggest a review of legal organisations, especially in their structures, marketing mix, and purposes. There is almost nothing in them that comes close to business organisations. First, virtually all of them are government entities. It is the federation, for example, that creates the Federal Constitution, just as states and municipalities are responsible for making their respective constitutions. In these more extensive laws, the competencies to produce all laws are determined. The 'big industry' of laws, therefore, originates from the government. The government and those it delegates competence to prioritise marketing efforts and organisation of the legal supply chain.

Table 3 Summary of the conceptual definition of legal marketing

\begin{tabular}{lccc}
\hline Marketing type & Structure & Marketing mix & Purpose \\
\hline Legal business & Diversified & Complete & Profit \\
Attorney services & Diversified & Complete & Profit \\
Legal & defined & Incomplete & Social harmony \\
\hline
\end{tabular}

Source: Prepared by the authors

If there are a production system and even a supply chain of laws, marketing structures are necessary. Every production system is an organisational strategy that can be called an institutional strategy in the legal supply chain. The government and the institutions it delegates need to create their marketing structures to execute the plan. They do it internally, through the division of labour, tasks, and resources (Silva et al., 2019a; Eugenia et al., 2019; Hanafi, 2019), as well as externally (Muhibbullah and Karim, 2016; Clarke, 1999), through diplomatic relations and participation in international organisations. These to achieve the objectives and goals (Membiela-Pollán, 2019) of each institution that is part of the legal chain supply. Table 3 summarises the implications of the definition of legal marketing in its structural, operational, and teleological aspects. 
The study by Simões and Nascimento-e-Silva (2020) showed that, except for the price, the marketing mix is entirely in legal marketing. It is because laws as a product do not have a defined price since everyone's contributions finance them through their taxes. However, as companies providing legal services and freelance lawyers are part of the law distribution system, working with one of their operators. As their services consume their resources, they are appropriately funded and priced. As participants in the legal supply chain, these companies and professionals' services have cost and present all the different marketing mix Ps.

Finally, institutions' teleological nature of legal marketing to do so is the common good. In contrast, companies' purpose of marketing, business associations, and professionals who sell legal services is profit. These companies, associations, and professionals do not practice legal marketing, but corporate marketing (in the case of companies and their associations) and attorney marketing, in lawyers' case. Only government institutions and organisations delegate the practice of legal marketing. All other organisations and their professionals practice, in some way, only business marketing.

\section{Conclusions}

This study showed that legal marketing promotes the common good by drafting laws that promote social harmony. The process systematised in terms of sequential steps, logically ordered, to produce, as an effect, the creation of value, which is what the users of the laws need to supply their needs. This value is the common good, not customer satisfaction. As there are no customers, there is no profit, an essential element in business marketing. Therefore, legal marketing is the government, the only entity capable of producing laws and institutions delegated by it; except for the government and these empowered institutions, everyone practices corporate marketing, not legal marketing.

Marketing is a managerial tool. And as such, it is linked to the production and operation systems. Organisations use communication channels to inform how their products and services create value for their customers by meeting their needs. Legal marketing, in turn, is linked to the law-making system of a community or nation and, therefore, serves to create value for associated human life, meeting the relational regulation needs of its members through different communication channels. The purpose of laws is always social harmony.

Thus, legal marketing emerges to assist institutions in the challenge of safeguarding communities' rights as a common good for all. Legal marketing is at the service of those who make the law and is responsible for supervising its application. It is a pedagogical and conscientious instrument, first because it instructs people to know what they can and what they are allowed to do; second, the knowledge of spaces for freedom of action will enable individuals to be aware of their limits importance of valuing them. It, it seems, is the role that legal marketing must play according to the original concept of marketing.

As a recommendation for future studies, we suggest analysing how government institutions execute the marketing process. In this way, environmental analyses, the process of formulating marketing plans, institutional structuring, procedures for elaborating the marketing mix, and evaluating the law's effectiveness in bringing about social harmony are the focus of the study. 


\section{References}

Agapito, D., Mendes, J. and Valle, P. (2013) 'Exploring the conceptualization of the sensory dimension of tourist experiences', Journal of Destination Marketing and Management, Vol. 2, No. 2, pp.62-73.

Agapito, D., Pinto, P. and Mendes, J. (2012) Sensory Marketing and Tourist Experiences, Spatial and Organizational Dynamics Discussions Papers, No. 10, pp.7-19.

Aggarwal, V.S. and Kapoor, M. (2020) 'Multigroup analysis of higher-order model of knowledge variables in the context of global ventures through PLS-SEM', South Asian Journal of Business Studies [online] https://doi.org/10.1108/SAJBS-02-2020-0037.

Ali, J. and Kachroo, J. (2020) 'Marketing analysis of the commercial cultivars of apple in mountainous and inaccessible areas of Chenab Valley', Indian Journal of Economics and Development, Vol. 16, No. 2, pp.239-246 [online] https://doi.org/10.35716/IJED/19111.

Almakhadmah, I.M. and Ajloun, J. (2019) 'The role of the tourist mix in activating Christian religious tourism in Madaba Governorate, Jordan', African Journal of Hospitality, Tourism and Leisure, Vol. 8, No. 3, pp.1-15.

Al-Zyoud, M.F. (2019) 'Employing marketing mix to increase the efficiency of CRM within organic products marketers in Jordan', Marketing, Vol. 15, No. 2, pp.84-95 [online] http://dx.doi.org/10.21511/im.15(2).2019.07.

Alabina, T. and Mishchenko, V. (2019) 'Economic research of development strategies abroad, in the USSR and modern Russia: a brief overview and systematization', in Volgograd State University International Scientific Conference 'Competitive, Sustainable and Safe Development of the Regional Economy' (CSSDRE 2019) [online] https://doi.org/10.2991/ cssdre-19.2019.75.

Araújo, F.N.M. et al. (2020) 'Interface entre Missão e Propósito das Empresas Brasileiras B Corporations', Management in Perspective, Vol. 1, No. 2, pp.169-186 [online] https://doi.org/10.14393/MIP-v1n2-2020-49428.

Awada, H. (2019) 'An investigation of the relationship between organizational structure, tie strength, and tacit knowledge sharing', in European Conference on Knowledge Management, Academic Conferences International Limited, pp.1215-1216.

Bashir, M. and Verma, R. (2019) 'Internal factors and consequences of business model innovation', Management Decision, Vol. 57, No. 1, pp.262-290 [online] https://doi.org/10.1108/MD-112016-0784.

Bennett, P.D. (1995) Dictionary of Marketing Terms, 2nd ed., American Marketing Association, Chicago, IL.

Beqaj, B., Krasniqi, A. and Beqaj, V. (2019) 'Consumer satisfaction on online services in Kosovo', Zagreb International Review of Economics and Business, Vol. 22, No. s2, pp.39-53 [online] https://doi.org/10.2478/zireb-2019-0026.

Blagorazumnaia, O. and Robu, E. (2020) 'The marketing strategies in innovative development of higher education institutions', EcoSoEn, Nos. 1-2, pp.38-45.

Bodet, G. and Séguin, B. (2020) 'Team sports brand management', in Walzel, S. and Römish, V. (Eds.): Managing Sports Teams, pp.141-159, Springer, Cham [online] https://doi.org/10.1007/ 978-3-030-56495-7_8.

Bran-Piedrahita, L., Valencia-Arias, A. and Palacios-Moya, L. (2020) 'Strategic marketing planning challenges for health sector organizations', Suma de Negocios, Vol. 11, No. 25, pp.108-115 [online] https://dx.doi.org/10.14349/sumneg/2020.v11.n25.a2.

Clarke, J. (1999) 'Marketing structures for farm tourism: beyond the individual provider of rural tourism', Journal of Sustainable Tourism, Vol. 7, No. 1, pp.26-47.

Coelho, E.D.A., Fonseca, P.G. and Daltro, E.F.M.A. (2020) 'Effectiveness of organizational mission of the public security secretaries of the Brazilian states', Independent Journal of Management and Production, Vol. 11, No. 2, pp.419-437 [online] https://doi.org/10.14807/ ijmp.v11i2.1047. 
Constantinescu, M. and Marinescu, G. (2014) 'The digitization of the economy and the remodeling of the marketing strategies' [online] http://dx.doi.org/10.2139/ssrn.2392707.

Delospital, F.R. (2016) Aplicação do Auxilio Multicritério à Decisão ao Projeto de Travessia Entre Santos e Guarujá, Unpublished Master thesis, Universidade Estadual de Campinas, Campinas, Brazil.

Deng, L.H., He, J. and Li, Y. (2020) 'Multi-channel structure selection model for minor enterprises', in Proceedings of the Seventh International Forum on Decision Sciences, pp.11-20, Springer, Singapore.

Dias, M.A.R.T. (2018) Plano de Marketing Para o Grupo 'Quiosque Lisboa', Unpublished Master thesis, Universidade de Lisboa, Lisboa, Portugal.

Escudeiro, P.F.M., Negrão, K.R.M. and Saboya, S.M.P. (2019) 'Estratégias de marketing jurídico para posicionamento de escritórios de advocacia em Belém', Revista de Administração e Contabilidade da Faculdade Estácio do Pará, Vol. 6, No. 11, pp.94-116.

Eugenia, J., Oproescu, M. and Tudosoiu, D. (2019) 'Romanian pre-university education from the perspective of school management', in 2019 11th International Conference on Electronics, Computers, and Artificial Intelligence (ECAI), pp.1-5, IEEE.

Ferreira, E.M.M. (2018) Abordagem ao Neuromarketing e a Sua Relação Com o Marketing Digital, Unpublished Master thesis, Instituto Politécnico do Porto, Porto, Portugal.

Ferreira, G.V., Arantes, R.C. and Ferreira, A.C. (2019) 'Hábitos de compra e satisfação de consumidores universitários com relação ao mobile-commerce', Revista Gestão and Conexões, Vol. 8, No. 3, pp.123-140 [online] https://doi.org/10.13071/regec.2317-5087.2019. 8.3.23718.123-140.

Fonseca, D.F.M. (2018) A Utilização de Aplicações Móveis em Festivais de Música, Unpublished Master thesis, Instituto Politécnico do Porto, Porto, Brazil.

Forozandeh, M., Teimoury, E. and Makui, A. (2018) 'A model for network design of supply chain management in research projects', Uncertain Supply Chain Management, Vol. 6, No. 4, pp.407-422 [online] https://doi.org/10.5267/j.uscm.2017.12.004.

Fulaneti, O.N. (2010) Utopias em Rotação: Análise do Discurso da Esquerda Armada Brasileira, Unpublished PhD thesis, Universidade de São Paulo, São Paulo, Brazil.

Gebra, F.M. and Ferranti, T.R. (2010) 'Do mito sacrificial à alquímica união dos opostos: o duplo em 'Um desejo e dois irmãos', de Marina Colasanti', UniLetras, Vol. 32, No. 2, pp.395-411 [online] http://dx.doi.org/10.5212/Uniletras.v.32i2.0013.

Gebretsadik, D. (2020) 'Marketing chain and structure, conduct and performance of sesame: the case of Kafta Humera district, Western Zone of Tigray, Ethiopia', Asian Journal of Agricultural Extension, Economics and Sociology, pp.14-36 [online] https://doi.org/10.9734/ ajaees/2020/v38i230306.

Gil, N.R.A. (2018) Marketing Preditivo: Exemplo de Uma Campanha de Crédito Pessoal, Unpublished Master thesis, Universidade Nova de Lisboa, Lisboa, Portugal.

Goi, C.L. (2009) 'A review of marketing mix: 4Ps or more?', International Journal of Marketing Studies, Vol. 1, No. 1, pp.2-15.

Gowsalya, T., Kanaga, V. and Faizullah, M.M. (2020) 'Analysis of fish production status and marketing structure in Aliyar Reservoir, Tamil Nadu', Indian Journal of Animal Research, Vol. 54, No. 9, pp.1159-1165 [online] http://doi.org/10.18805/ijar.B-3875.

Hanafi, A.S. (2019) 'Effect of organizational structure, job analysis and leadership style on work motivation and its impact on performance of employees', Journal of Public Administration Studies, Vol. 4, No. 1, pp.39-45 [online] https://dx.doi.org/10.21776/ub.jpas. 2019.004.01.8.

Hersberger-Langloh, S.E., Stühlinger, S. and von Schnurbein, G. (2020) 'Institutional isomorphism and nonprofit managerialism: for better or worse?', Nonprofit Management and Leadership [online] https://doi.org/10.1002/nml.21441. 
Jadhav, G. and Borgave, S. (2020) 'Marine fish marketing structure and constraints in Palghar district', Shod Sharita, Vol. 7, No. 25, pp.342-346.

Joyce, M., David, J. and Titus, J. (2019) 'Structure of red pepper marketing in Adamawa State, Nigeria', International Journal of Veterinary Science and Agriculture Research, Vol. 1, No. 3, pp.16-21.

Junita, A., Saragih, F.D. and Atmoko, A.W. (2020) 'Contingency perspective of strategic HRM in the system dynamics model: the case of the branch office of PT Bank Rakyat Indonesia, TBK in Medan Regional Office, Indonesia', International Journal of Management and Administrative Sciences, Vol. 6, No. 4, pp.11-33.

Kaiyp, K. and Alimanova, M. (2020) 'Improving indicators of digital marketing using artificial intelligence', Suleyman Demirel University Bulletin: Natural and Technical Sciences, Vol. 52, No. 1, pp.54-63 [online] https://doi.org/10.47344/sdubnts.v52i1.71.

Khorsheed, R.K. et al. (2020) 'The role of services marketing mix 7P's on achieving competitive advantages (the case of Paitaxt Technical Institute in Kurdistan Region of Iraq)', Test Engineering and Marketing, Vol. 83, No. 2, pp.15947-15971.

Khosravizadeh, O. et al. (2020) 'The branding process for healthcare centers: operational strategies from consumer's identification to market development', International Journal of Healthcare Management, pp.1-9 [online] https://doi.org/10.1080/20479700.2020.1723881.

Kong, X., Liu, D. and Min, L. (2020) 'VR technology in marketing from the perspective of customer experience', IEEE Access, Vol. 8, pp.162581-162587 [online] https://doi.org/ 10.1109/ACCESS.2020.3021690.

Kotler, P. (1994) Marketing Management, Analysis, Planning, Implementation, and Control, Prentice-Hall, Englewood Cliffs.

Kotler, P. et al. (2006) Principle of Marketing, 5th ed., Prentice-Hall, Upper Saddle River.

Kumar, S. and Almoula, T.S. (2020) 'A comparative study of customer service level based on service marketing mix (7Ps) in selected public and private sector banks in Bhopal, MP, India, by using mystery shopping as a tool', International Journal of Financial Services Management, Vol. 10, No. 3, pp.239-267 [online] https://doi.org/10.1504/IJFSM.2020. 111106.

Lagzouli, A. et al. (2020) 'The constructive relationship between logistics and marketing: theoretical framework', Strategy Management Logistics, Vol. 1, No. 1, pp.1-6.

Leão, R.R.R., Barbosa, L.A. and Storniolo, L.S. (2019) '(Des)estrutura das instituições sociais e a liquidez das relações na contemporaneidade', Humanidades \& Inovação, Vol. 6, No. 7, pp.101-109.

Legal Marketing Association (LMA) (2020) You're Invited: Join LMA, LMA.

Liang, X. and Gao, Y. (2020) 'Marketing performance measurement systems and firm performance', European Journal of Marketing, Vol. 54, No. 4, pp.885-907 [online] http://doi.org/10.1108/EJM-05-2018-0302.

Macedo, G.A., Silva, E.E. and Silva, M.E. (2018) 'Vaidade masculina: hábitos e influência na decisão de compra do público masculino de produtos cosméticos numa empresa no município de Teófilo Otoni-MG', Brazilian Journal of Development, Vol. 4, No. 6, pp.3532-3552.

Majercak, J., Kudlac, S. and Ponicky, J. (2016) 'Innovative management of supply chains', Logi-Scientific Journal on Transport and Logistics, Vol. 7, No. 1, pp.98-107.

Marques, A.C.F. (2009) Aplicação do Apoio Multicriterio a Decisão ao Projeto do Aeroporto Industrial de Viracopos, Unpublished Master thesis, Universidade Estadual de Campinas, Campinas, Brazil.

Maulana, T. and Susandy, G. (2019) 'The influence of viral marketing and price discounts through social media Instagram to purchase decision on marketplace Shopee', Dimensia (Diskursus Ilmu Manajemen STIESA), Vol. 16, No. 2, pp.1-10. 
Meltem, Ö.Z.E.N. and Mevlüt, G.Ü.L. (2020) 'Marketing structure of apricot production and analysis of its problems: a case of Mut district in Mersin province', International Journal of Agriculture Forestry and Life Sciences, Vol. 4, No. 1, pp.79-86.

Membiela-Pollán, M. (2019) 'Social capital: its role in marketing praxis through 17 ideas', Redmarka. Revista de Marketing Aplicado, Vol. 23, No. 2, pp.75-96 [online] https://doi.org/ 10.17979/redma.2019.23.2.5837.

Mendes, C.F.P.F. (2018) Estágio na Empresa Hudson Shoe Agencies, UK, Unpublished Master thesis, Universidade Portucalense, Porto, Portugal.

Montoya-Restrepo, L.A., Montoya-Restrepo, I.A. and Rojas-Berrio, S. (2020) 'Marketing research processes. A perspective of the future from a qualitative view', Libros Poli, Vol. 253,No. 1, pp.111-130.

Moura, A.L., Santos, D.F.L. and Conceicao, E.V. (2019) 'Proposal for a financial management model applied to a small business in the fertilizer segment', Revista de Empreendedorismo $e$ Gestao de Pequenas Empresas, Vol. 8, No. 3, pp.36-69.

Mudzanani, T.E. and Molaoa, T.A. (2018) 'Factors affecting consumers' choice of mobile communication service providers in the City of Tshwane', African Journal of Business and Economic Research, Vol. 13, No. 3, pp.175-203 [online] https://doi.org/10.31920/17504562/2018/v13n3a9.

Muhammad, J.M.S. et al. (2020) 'Structure and performance of catfish marketing in Dankure market Sokoto, Sokoto State, Nigeria', Equity Journal of Science and Technology, Vol. 7, No. 1, pp.60-66.

Muhibbullah, M. and Karim, R. (2016) 'An observation on marketing structure and strategy for future expansion of poultry in Bangladesh', Asian Review, Journal of Asian University of Bangladesh, Vol. 5, No. 1, pp.17-41.

Nascimento-e-Silva, D. (2012) Manual de Redação para Trabalhos Acadêmicos: Position Paper, Ensaios Teóricos, Artigos Científicos e Questões Norteadoras, Atlas, São Paulo.

Nascimento-e-Silva, D. (2020) Manual do Método Científico-Tecnológico, DNS Editor, Manaus.

Neis, D.F., Pereira, M.F. and Maccari, E.A. (2017) 'Strategic planning process and organizational structure: impacts, confluence and similarities', Brazilian Business Review, Vol. 14, No. 5, pp.479-492 [online] https://doi.org/10.15728/bbr.2017.14.5.2.

Nogueira, E.C.S. (2018) Estratégia para Implementação de Uma Plataforma de E-Commerce no Mercado Francês: E-Geonext France, Unpublished Master thesis, Instituto Politécnico do Porto, Porto, Portugal.

Nugraha, K.S., Astuti, N.N.S. and Armoni, N.L.E. (2020) 'Marketing strategy in enhancing competitive advantage at Mercure Chamonix Center Hotel, France', Journal of Applied Sciences in Travel and Hospitality, Vol. 3, No. 2, pp.116-124 [online] http://dx.doi.org/ 10.31940/jasth.v3i2.1928.

Opriş, M.A., Brătucu, G. and Palade, A. (2014) 'The impact of eco-marketing-a quantitative research on the Brasov's adult population', International Journal of Economic Practices and Theories, Vol. 4, No. 5, pp.711-717.

Östborn, P. (2018) Quantum Mechanics from an Epistemic State-Space, pp.1-54, arXiv preprint arXiv:1703.08543.

Özenç, S. and Mevlüt, G.Ü.L. (2020) 'Distribution channel structure of greenhouse capia peppers (Capia piperis) production and analysis of its problems: the case of Kaş district of Antalya province', International Journal of Agriculture Forestry and Life Sciences, Vol. 4, No. 1, pp.8-13.

Pagura, R.J. (2010) A Interpretação de Conferências no Brasil: História de Sua Prática Profissional e a Formação de Intérpretes Brasileiros, Unpublished $\mathrm{PhD}$ thesis, Universidade de São Paulo, São Paulo, Brazil. 
Paiero, P.C. (2011) As Marcas da Oralidade em Jornais Populares: Um Estudo Sobre os Editoriais do Jornal Agora São Paulo, Unpublished Master thesis, Universidade Prebisteriana Makenzie, São Paulo, Brazil.

Pater, L.R. and Cristea, S.L. (2018) 'A systemic characterization of organizational marketing', Procedia - Social and Behavioral Sciences, Vol. 238, pp.414-423 [online] https://doi.org/ 10.1016/j.sbspro.2018.04.019.

Peng, W. (2019) 'Theoretical thinking on the organization of 'strategic defects", Journal of Membrane Technology, Vol. 1, pp.1-3 [online] https://doi.org/10.23977/membt.2019.11001.

Peters, K. and Remaud, P.H. (2020) 'Factors influencing consumer menu-item selection in a restaurant context', Food Quality and Preference, No. 82, p.103887 [online] https://doi.org/ 10.1016/j.foodqual.2020.103887.

Pong, K.S. and Chin, Y.S. (2020) 'Applying a promotional mix in promoting Bujang valley: a perspective from tourists', Tourism and Sustainable Development Review, Vol. 1, No. 2, pp.119-134 [online] https://doi.org/10.31098/tsdr.v1i1.20

Queiroz, E.F. (2018) A Influência dos Atributos Educacionais dos Cursos Profissionalizantes na Empregabilidade, Unpublished Master thesis, Universidade Fumec, Belo Horizonte, Brazil.

Quintas, O.P. (2018) Plano de Marketing para a Escola Técnica e Profissional do Centro Politécnico, Unpublished Master thesis, Universidade de Évora, Évora, Portugal.

Ramos, D.M. and Nascimento, V.G. (2008) 'A família como instituição moderna', Fractal: Revista de Psicologia, Vol. 20, No. 2, pp.461-472 [online] https://doi.org/10.1590/S198402922008000200012.

Ravangard, R., Khodadad, A. and Bastani, P. (2020) 'How marketing mix (7Ps) affect the patients' selection of a hospital: experience of a low-income country', Journal of the Egyptian Public Health Association, Vol. 95, No. 1, pp.1-8 [online] https://doi.org/10.1186/s42506-02000052-z.

Roache, D. (2019) 'The competitive advantages of doctoral learners obtaining degrees in educational administration: an exploration of knowledge, marketability, and comparative advantage in the international marketplace review article' [online] http://dx.doi.org/10.2139/ ssrn.3405019.

Rocha, S.R.A. (2018) Elaboração de um Plano de Marketing para a Empresa António Carlos Rocha, Construção e Obras Públicas, LDA, Unpublished Master thesis, European Business School, Porto, Portugal.

Sales, F.E. and Sousa, P.D.B. (2018) 'Ferramentas de marketing para análise do consumidor no mercado de varejo', Revista Conbrad, Vol. 3, No. 2, pp.103-124.

Santos, W.L. (2019) Análise do Modelo Conceitual do SIGAD a Partir de Princípios da Ontologia de Fundamentação UFO, Unpublished Master thesis, Universidade Federal Fluminense, Niterói, Brazil.

Sayyadi, M. (2019) 'What can executives take from social capital theory?', Muma Business Review, Vol. 3, No. 21, pp.237-244.

Severino, J.B. (2018) Análise das Práticas de Marketing do Instituto Federal do Triângulo Mineiro, Unpublished Master thesis, Instituto Politécnico do Porto, Porto, Portugal.

Shafiei, M. and Modarres, M. (2020) 'Optimisation of an integrated parallel distribution system by including network marketing', International Journal of Logistics Systems and Management, Vol. 36, No. 2, pp.305-318 [online] https://doi.org/10.1504/IJLSM.2020.107387.

Silva, H.C.C. et al. (2019a) 'The governance of information technology and its formal and informal mechanisms: proposing a framework for the context of small and medium enterprises', Revista de Empreendedorismo e Gestão de Pequenas Empresas, Vol. 8, No. 3, pp.200-231. 
Silva, I.J., Brito, N.E.S. and Oliveira, E.B. (2019b) 'Publicidade e marketing social como diferenciais competitivos: um estudo de caso do portal Nossa Causa', Paper presented at the XX Congresso de Ciências da Comunicação na Região Sul, Porto Alegre, Brazil, 20-22 June.

Silva, I.A., Felli, V.E.A. and Ciampone, M.H.T. (2002) 'Projeto pró-ABEn: subsídios e reflexões para o marketing da associação', Revista Brasileira de Enfermagem, Vol. 55, No. 4, pp.399-407.

Silva, R.O. et al. (2020) 'E-books como produtos educacionais: definição e tópicos de construção segundo o método científico-tecnológico', in Dickmann, I. (Ed.): Mosaico Temático I, pp.161-181, Livrologia, Chapecó.

Silvianita, A. and Ling, T.C. (2020) 'Role impact in knowledge management of automotive component firms in Indonesia', in First ASEAN Business, Environment, and Technology Symposium (ABEATS 2019), May, pp.79-82 [online] https://doi.org/10.2991/aebmr.k. 200514.018.

Simões, C.S. and Nascimento-e-Silva, D. (2020) 'Legal marketing: proposing an operational definition', Journal of Humanities and Social Science, Vol. 25, No. 7, pp.59-67 [online] https://doi.org/10.9790/0837-2507125967.

Sinanagić, A., Čivić, B. and Muratović, A. (2019) 'Presence of internet marketing and its influence of business success of companies in Bosnia and Herzegovina', Economic Review: Journal of Economics and Business, Vol. 17, No. 1, pp.77-89.

Souza, A.P.G., Oliveira, P.C. and Carvalho, A.B. (2018) 'A utilização do inbound marketing como estratégia de divulgação da nova marca de uma empresa do setor ferroviário em plataformas digitais', Revista de Administração do Unifatea, Vol. 17, No. 17, pp.1-25.

Stoica, I. et al. (2015) 'Online marketing communication using websites: a case study of website utility in accessing European funds in the tourism field regarding Northeastern Romania', Procedia Economics and Finance, Vol. 23, pp.926-935 [online] https://doi.org/10.1016/ S2212-5671(15)00436-0.

Sun, W., Ding, Z. and Price, J. (2020) 'Board structure and firm capability: an environment-embedded relationship between board diversity and marketing capability', Industrial Marketing Management, Vol. 90, pp.14-29 [online] https://doi.org/10.1016/ j.indmarman.2020.06.010.

Tikhonov, G.V. et al. (2020) 'Marketing as an effective control of progressive innovations', TEM Journal, Vol. 9, No. 3, pp.1094-1099.

Vilkey, A. and Dehbid, M. (2016) 'Strategic marketing management with Japanese management approach', J. Pol. and L., Vol. 9, pp.172-180 [online] https://dx.doi.org/10.5539/ jpl.v9n10p172.

Voskresenskaya, E., Shandova, N. and Sofiienko, A. (2020) 'Innovative approach to the formation of a system of strategic marketing management of tourism enterprises in conditions of market uncertainty', TEM Journal, Vol. 9, No. 3, p.1076.

Vynogradova, O. and Drokina, N. (2020) 'The structure of an integrated internet marketing complex, based on the marketing-mix concept', Acta Scientiarum Polonorum. Oeconomia, Vol. 19, No. 3, pp.117-126 [online] https://doi.org/10.22630/ASPE.2020.19.3.34.

Wahab, M.H.A.A.A. and Nazri, M.I.M. (2019) 'Influence of internal and external environmental factors on operational excellence of manufacturing sectors in Malaysia', International Journal of Academic Research in Business and Social Sciences, Vol. 9, No. 2, pp.961-970.

Wang, Y. et al. (2020) 'A thematic exploration of social media analytics in marketing research and an agenda for future inquiry', Journal of Strategic Marketing, pp.1-21 [online] https://doi.org/ 10.1080/0965254X.2020.1755351.

Widyaningsih, H. et al. (2020) 'Efficiency of papaya marketing (Carica papaya L.) in Indramayu regency, West Java Province of Indonesia', in International Conference on Agriculture, Social Sciences, Education, Technology and Health (ICASSETH 2019), pp.111-114. 
Xaiver, J., Dewi, L.K.C. and Conçeicão, A. (2020) 'Marketing strategy analysis for developing a small-scale business in tourism, in Island Atauro tourism object, Dili Timor Leste', International Journal of Multicultural and Multireligious Understanding, Vol. 7, No. 8, pp.549-561 [online] http://dx.doi.org/10.18415/ijmmu.v7i8.1968.

Yaghin, R.G. (2020) 'Enhancing supply chain production-marketing planning with geometric multivariate demand function (a case study of textile industry)', Computers and Industrial Engineering, Vol. 140, p.106220 [online] https://doi.org/10.1016/j.cie.2019.106220.

Yeserah, S., Jenberie, A. and Begna, D. (2019) 'Honey marketing, structure and conduct of honey market in Gozamen district, East Gojjam Zone, and Amhara region', Cogent Food and Agriculture, Vol. 5, No. 1, p.1620153 [online] https://doi.org/10.1080/23311932.2019. 1620153.

Zaharia, V. and Dogaru, M. (2013) 'The digitization of the economy and the remodeling of the marketing strategies', Social Economic Debates, No. 2/2013, pp.22-70.

Zineldin, M. and Philipson, S. (2007) 'Kotler and Borden are not dead: myth of relationship marketing and truth of the 4Ps', Journal of Consumer Marketing, Vol. 24, No. 4, pp.229-241 [online] https://doi.org/10.1108/07363760710756011. 